\title{
Organizational Law as Asset Partitioning
}

By: Henry Hansmann and Reinier Kraakman

Working Paper Number 252

September 1999 


\title{
ORGANIZATIONAL LAW AS ASSET PARTITIONING
}

\author{
by \\ Henry Hansmann \\ Yale Law School \\ and \\ Reinier Kraakman \\ Harvard Law School
}

September 1999

Paper prepared for the conference on Corporate Governance at The Davidson Institute, Ann Arbor, Michigan, September 24-5, 1999.

Send correspondence to: Henry Hansmann

Yale Law School

P.O. Box 208215

New Haven, CT 06520-8215

203-432-4966

203-432-1040 fax

henry.hansmann@yale.edu

Reinier Kraakman

Harvard Law School

Cambridge, MA 02138

617-495-3586

617-495-1110 fax

kraakman@law.harvard.edu 
Abstract:

Organizational law - comprising the bodies of law that govern standard legal entities such as business corporations, partnerships, cooperatives, nonprofit organizations, trusts, limited liability companies, and marriages - serves many functions of an essentially contractual character. These contractual functions -which include most matters involving the allocation of authority and earnings among the participants in the firm - could, however, be performed relatively easily by private contracting even in the absence of organizational law. A far more important function of organizational law, we argue, is its role in partitioning property rights between creditors of a firm and creditors of the firm's owners and managers. In particular, organizational law plays a crucial role in permitting the formation of a separate pool of assets that can be pledged to bond the contracts of which the firm is the nexus. While the law's role in partitioning off these bonding assets is seldom remarked, it is far more important than the betterstudied rule of limited liability that characterizes many, but not all, legal entities.

Keywords: asset partitioning, legal entities, creditors, role of law 


\section{INTRODUCTION}

The law and economics revolution of the past several decades, which has brought the systematic application of economic analysis to the study of basic legal rules and institutions, has had a particularly strong impact on the study of corporate law, and of organizational law in general. One conspicuous consequence has been an increasing tendency to view organizational law in contractual terms. More particularly, the economic analyst is inclined to see nearly all aspects of organizational law as terms in an explicit or implicit contract among the affected parties.

As a consequence, we are naturally led to ask what it is that organizational law adds to contract law. Why does the law establish a set of basic organizational forms for organizing enterprise, rather than leaving the whole field to contract? What would we lose if we were to eliminate all of organizational law, or any part of it, and simply rely upon the general rules of contract law to fill the gap?

In the United States, for example, the law provides for a variety of distinct standard forms for organizing economic activity, including the business corporation, the cooperative corporation, the nonprofit corporation, the municipal corporation, the limited liability company, the general partnership, the limited partnership, the private trust, the charitable trust, and marriage. Other countries with developed market economies typically provide for a roughly similar set of forms, though with some variations in both number and nature. What function is served by these forms? Are they simply convenient standard form contracts that supply off-the-rack contractual terms for the most common types of organizational arrangements, serving only to save businesspeople and their lawyers the bother of drafting up their own terms? Or does the law play some more essential role in the formation of organizations? Despite the enormous volume of scholarship on organizational law -- and particularly corporate law -- in recent years, the existing literature still offers no clear answer to this basic question. We suggest an answer here.

For convenience, we will use the term "legal entities" here to refer to organizational forms -- such as the business corporation, the general partnership, and marriage -- that are established by law, and we will refer to the law that creates and regulates legal entities as "organizational law." 


\section{LEGAL ENTITIES AS LOCI FOR CONTRACTING}

There are, broadly speaking, two ways to coordinate the economic activity of two or more individuals. The first is by having those individuals contract directly with each other on their own account. The second is by having each of those individuals enter into a contract with a third party who undertakes the coordination through design of the separate contracts and -- most importantly -- through exercise of the discretion given the third party by those contracts. A third party that serves this coordination function is what we commonly call a firm. Or, to use the nowconventional terminology, a firm serves as the requisite "nexus of contracts" for the persons whose activity is to be coordinated -- that is, as the common party to individual contracts with those persons.

Economic theory does not offer a completely satisfactory explanation for the fact that productive activity today is commonly organized in the form of very large loci of contracts, in which a central actor contracts simultaneously with employees, suppliers, and customers who may number in the thousands or even millions. Why, for example, are organizations not constructed in the form of contractual cascades, in which each party contracts not with the firm but with his or her immediate superior, so that the pattern of contracts corresponds to the authority relationships we see in a standard pyramidal organizational chart? We will not tackle this question here, however, but rather will simply take for granted that, to create a modern market economy, it is essential that such large loci of contracts can be constructed. ${ }^{1}$

1. The literature that focuses on asset specificity to explain vertical integration is of course important here (e.g., Klein, Crawford, \& Alchian; Williamson (1986)), as is the "property rights" approach to the theory of the firm that has evolved out of that literature, most conspicuously in the work of Hart \& Moore (e.g., Hart (1995)). A related but somewhat different reason for large centralized loci (as opposed, e.g., to more decentralized structures) may be the need to avoid opportunistic threats to disassemble a set of transactional relationships that has been costly to assemble, or to expropriate an entrepreneur's or organization's accumulated experience with working procedures and forms of organization (Rajan \& Zingales (1998)). All of this literature, however, seems to leave important things unexplained (Hansmann (1996) at 15 \& 15 n. 8). 


\section{The Nature of a Legal Entity: Managers, HBIs, and Bonding Assets}

To serve effectively as a locus of contracts, a firm must have at least two attributes. The first is well-defined decision-making authority. More particularly, there must be one or more persons who possess ultimate authority to commit the firm to contracts. We will term those persons the managers of the firm. The managers may or may not be distinct from the persons for whose benefit the managers are acting, whom we will term the holders of the beneficial interest (HBIs). We use the latter term, rather than the more familiar "residual claimants," to avoid the implication that the persons in question necessarily have an interest only in the firm's net cash income, or that they necessarily have some means of insisting on ("claiming") benefits from the firm or, indeed, of exercising any form of control over the firm's managers at all. That implication would be inaccurate, for example, for legal entities such as nonprofit corporations and trusts, and arguably is not strictly accurate even for business corporations (whose creditors or employees may, for some purposes, also be HBIs).

The second attribute is a reasonably well-defined pool of assets -- which we will term the firm's bonding assets -- that the managers of the firm can pledge as security for performance of the firm's contracts. Bonding assets serve the obvious function of permitting the firm to assure its creditors that the firm will not exploit them by opportunistically defaulting on its obligations. Also, quite apart from problems of opportunism, bonding assets permit unavoidable risks associated with the firm's business to be shifted from the firm's creditors to its HBIs, which may result in more efficient risk-bearing.

A natural person has the two attributes just described and hence can -- and very frequently does -- serve as a firm, in the form of a sole proprietorship. In this case, there is a single individual who is both manager and HBI, and the bonding assets consist of all of the assets owned by that individual. Note, however, that individuals have these attributes because the law provides them. In particular, the law gives an individual the ability to enter into contracts that will bind him in most future states, and provides that creditors of an individual have the right to levy on all assets owned by that individual if he defaults on his obligations to them.

Legal entities - often referred to, appropriately, as "juridical persons" - also have the two attributes described here. Legal entities are distinct from natural persons, however, in that their bonding assets are distinct from assets owned by the firm's HBIs or by the firm's manager(s), in the sense that the firm's creditors have a claim on the bonding assets that is prior to that of the personal creditors of the firm's HBIs or managers. More particularly, organizational law (1) permits the formation of a firm that can have ownership of assets of its own, and (2) establishes a pattern of creditors' rights under which creditors who contract with the firm have, as a default rule, the right to satisfy their claims out of assets held by the firm, while personal creditors of the firm's HBIs and managers have no such claim upon those assets (though personal creditors of the HBIs may be able to levy on the residual value of the HBI's interests in the firm after all of the firm's own creditors have first been satisfied). 
We view this pattern of creditors' rights as the essential characteristic of a legal entity, and its establishment as the essential contribution of organizational law to the furtherance of economic activity.

\section{Asset Partitioning}

This view can be labeled an "asset partitioning" theory of organizational law, where by "asset partitioning" we mean the division of a fixed pool of assets into subpools, each of which is separately pledged as security to a different creditor or group of creditors. The principal rationale for asset partitioning is to reduce the overall cost of credit when dealing with a heterogeneous group of creditors. The reason that asset partitioning can reduce costs is that some creditors are better able than others to monitor the value of particular assets, or to extract value from those assets when, upon default by the debtor, the creditor takes possession of them.

As an illustration, imagine an airline company that decides to go into the car rental business, hoping that there will be synergies between the two activities. Whether or not these synergies result, however, the two businesses will remain largely separate, in the sense that their suppliers, employees, and even customers will for the most part be distinct. Should the two businesses be operated as part of the same corporation, with the car rental operation organized simply as a separate division? Or should the car rental operation be separately incorporated, with all of its stock held by the airline company (or by a holding company that also owns all the stock of the airline company)?

The two businesses are likely to be managed much the same in either case. But, while the aggregate assets of the two businesses will also be the same, the separate incorporation approach may significantly reduce the aggregate cost of credit. The reason is that the firms that extend credit to the car rental business - such as the auto manufacturers who sell or lease cars to them often will be in a good position to assess the state of the overall car rental business, as well as the ability with which this particular car rental firm is managed, while at the same time they are largely ignorant of the prospects of the airline business. And the reverse is likely to be true of the creditors of the airline company (such as the airplane manufacturers that supply their planes).

If the two operations are combined in the same corporation, then creditors of either of the two businesses are always exposed to the risk that the other business will fail. Separate incorporation, in contrast, gives the creditors of the car rental business first priority claim on the car rental assets, which by virtue of corporation law are considered to be the separate property of the car rental corporation. Creditors of the airline operation, in turn, obtain first claim on the assets of the airline. The consequence is that creditors of one business are shielded from the vicissitudes of the other. Their perceived level of risk in extending credit therefore goes down, and the price they'll demand for credit goes down too.

In this example, the airline company (or the holding company) is the (single) HBI of the car rental business. But much the same logic applies when the HBIs are individuals, such as the shareholders in a business corporation or the partners in a partnership. In the latter cases, the asset 
partitioning that organizational law imposes is between the personal assets of the individual HBIs and the assets of the business. When a firm is organized as a legal entity -- whether as a corporation, a partnership, a trust, or a marriage -- the creditors of the firm have first priority claims against the assets to which the firm holds title, which must be satisfied before claims of the HBIs' personal creditors can be satisfied out of those assets. As a consequence, creditors of the firm can determine appropriate terms for credit in large part simply by monitoring the assets and prospects of the firm itself - which is to say, the net value of the assemblage of contracts and property rights that the firm possesses.

If the firm is a limited liability entity, such as a corporation, the partitioning is complete for the creditors of the firm: they have no claim on the owners' personal assets, and can therefore confine themselves entirely to monitoring the assets of the firm itself, and ignore the personal affairs and other business activities of the firm's owners. If, as in a partnership, the owners have personal liability for the unpaid debts of the firm, then the firm's creditors retain an interest in monitoring the assets of the individual owners. But this question of the owners' personal liability for a firm's debts, as we shall argue further below, is a secondary matter.

For the personal creditors of a firm's owners, the asset partitioning established by organizational law is less well defined. Whether the firm is a limited liability entity or an unlimited liability entity, the owners' personal creditors commonly maintain an interest in monitoring the creditworthiness of the firm, since with most types of legal entities -- though not all -- they have a potential claim on the entity's residual value. But even here, organizational law induces at least partial partitioning between business and personal assets and, to the extent that personal creditors have a relative advantage over business creditors at monitoring personal assets, this partitioning promotes efficiency in contracting.

\section{WHY IS LAW NECESSARY?}

Our argument here has four elements: (1) that a characteristic of all legal entities, and hence of organizational law in general, is the partitioning off of a set of separate firm assets in which creditors of the firm itself have a prior security interest; (2) that this partitioning has important efficiency advantages; (3) that it would generally be infeasible to establish this form of asset partitioning without organizational law; and (4) that this is the only crucial contribution of organizational law to the organization of enterprise. We turn now to the third of these claims. We address the fourth claim in Sections IV and V.

Conceptually, what we wish to ask here is the following: If all statutory and decisional law specifically related to legal entities were repealed - that is, if we were to eliminate the special bodies of law applicable to business corporations, partnerships, cooperatives, and so forth - how difficult would it be to form firms using just the remaining general tools of property law, contract 
law, and agency law? ${ }^{2}$

It would not be difficult to establish the basic nexus of contracts structure, either under the civil law systems of continental Europe or under the Anglo-American common law systems. The obvious approach would be for the firm's prospective HBIs simply to appoint one or more persons as their common agent to manage the firm's affairs, with full authority to contract on their behalf with respect to matters involving the firm's business.

The problem, rather, lies in asset partitioning. Absent organizational law, the firm could not be established as a juridical person that could hold title to assets in its own right. This does not mean that the manager of the business -- the HBIs' collective agent -- would have no bonding assets with which to secure the firm's contracts. On the contrary, the HBIs could authorize their agent to commit the HBIs' personal assets as security for the firm's contracts. Indeed, standard agency law would presume that all of the HBIs' personal assets served this role. This approach has the serious problem, however, that the personal creditors of the owners would have a claim on the business's bonding assets equal to that of the business creditors of the firm. This would be a problem not only because it would increase the cost of risk assessment facing the business creditors, or because it might establish an inefficient pattern of risk sharing among the HBIs and their personal and business creditors, but also because it would bring the threat of moral hazard on the part of the HBIs, who would have both the ability and the incentive to explicitly or implicitly pledge the firm's assets to support their individual activities (including their other business investments).

These problems might be avoided by having the HBIs transfer, to the agent, title to a pool of assets sufficient to serve as the bonding assets for the business, subject to the agent's contractual promise to employ those assets only in the designated business, and only for the benefit of the owners. The bonding assets would then be shielded from the claims of the HBIs' personal creditors, since they would no longer be owned by the HBIs. But this approach would make the bonding assets subject to claims of the agent's personal creditors, thus putting the business's creditors at the risk of the insolvency of the agent (i.e., the business's manager).

Whether title to the business's bonding assets is held by the business's HBIs or by its manager, it would be possible in theory to use contractual means to partition off the bonding assets from the claims of other creditors. In the case in which title to the business assets is held by the HBIs, each HBI could insert, into each personal contract he enters into, a provision whereby the other party to the contract waives any recourse, in case of nonperformance, against the assets used in the business. The transaction costs of this form of contracting would be immense, however, for such clauses would have to be inserted in all personal and (other) business contracts, both existing and new, entered into by all of the firm's HBIs. Beyond the negotiating and drafting costs involved, there would remain the essentially insurmountable problem of moral hazard, since

2. For more extensive treatment of this issue, see Hansmann \& Kraakman (1999). 
each individual HBI would have an incentive to omit the relevant provision in some of his contracts (especially those involving other business investments), and such behavior would be extremely difficult for the other HBIs, or the creditors of the business, to police. In the case in which the owners transfer title in the business assets to the firm's manager, there would be similar difficulties. The manager would have to place an appropriate waiver in all contracts with his other personal and business creditors, and the owners and creditors of the firm would face the problem of assuring themselves that he did this.

Organizational law eliminates the need for such contracting, and the transaction costs and moral hazard associated with it. By permitting the firm itself to be an "owner" of assets, the law permits business assets to be insulated easily from claims of the individual creditors of the firm's owners or managers. In this respect, organizational law operates as a form of property law, permitting changes in rights that bind third parties. When a firm is organized as a legal entity, and an owner of that firm - even the sole owner - transfers assets to the firm, the creditors of the firm are automatically given a contingent claim on those assets (exercisable in case of contractual default), while the contingent claim on those assets held by the owner's personal creditors is eliminated (or at least subordinated to the claims of the firm's creditors), all without any form of recontracting or assent on the part of the owner's personal creditors or the creditors of the business.

Organizational law would not be necessary for this purpose if the law in general were more flexible in permitting the creation and assignment of security interests in particular items of property. But the law of every country puts strong limits on the ways in which property rights can be subdivided, including the formation of contingent rights such as security interests. The principal reason for these limits is evidently to prevent the fractioning of property rights in ways that -- because of high transaction costs -- cannot be undone through private contracting if and when the fractioning becomes inefficient. In the course of the twentieth century, the law of developed countries -- and particularly U.S. law -- has relaxed these limits by becoming increasingly flexible in permitting the free formation of complex security interests. If that liberalization continues, it may someday reach the point where a separate body of organizational law is unnecessary to accomplish the type of asset partitioning created by the formation of a legal entity. Until then, however, the formation of a large nexus of contracts will generally be infeasible without organizational law.

The basic efficiency advantage of asset partitioning -- the fact that the aggregate cost of credit can be reduced by appropriately dividing up a fixed pool of assets for purposes of pledging those assets as security to diverse creditors -- has long been familiar in the law and economics literature (Posner; Jackson \& Kronman; Levmore). Yet, surprisingly, the particular form of asset partitioning that is at the heart of organizational law -- insulation of a firm's assets from the individual creditors of the firm's owners or managers -- has to date gone largely unremarked.

\section{4. $\quad$ LIMITED LIABILITY}


In contrast, the existing literature in law and economics does focus extensively on the reverse form of asset partitioning: insulation of the personal assets of the firm's owners and managers from the creditors of the firm through the doctrine of limited liability. This form of asset partitioning, however, is both less important in efficiency terms, and less difficult to achieve through individual contracting without benefit of organizational law, than is the type of partitioning on which we have focused here.

To begin with, limited liability is not a characteristic of all legal entities. Partnerships, for example, lack this attribute. The reason for unlimited HBI liability is, of course, that in some cases the aggregate costs of credit are reduced by letting business creditors share with personal creditors a security interest in the owners' personal assets. At the same time, there are many firms, and especially large firms, for which this is not the case. Consequently, it is useful to make limited liability an option by providing for legal entities that do and do not have that attribute.

Moreover, there is good reason to believe that, even if limited liability were unavailable as an option, the formation of modern business firms would not be radically affected. It seems likely that, even with unlimited HBI liability, creditors of a firm that has thousands of HBIs would often take little account of the personal assets of the individual HBIs in establishing the firm's cost of credit, because the personal assets of the individual HBIs are simply too difficult to assess, monitor, and levy on. Consequently, for firms with dispersed ownership, limited liability probably has little affect on the firm's cost of credit. And, conversely, unlimited liability would probably have relatively modest consequences for the prices investors would pay for shares in large firms of the type that are today commonly incorporated (at least if the owners' personal liability were pro rata - i.e., proportional to the amount of their investment in the firm). That risk could easily be diversified, and it could be reduced to any arbitrarily small level by supplying the firm with sufficient bonding assets.

Finally, even if limited liability can lead to a substantial reduction in the aggregate cost of credit, organizational law is not essential to establish it. Even if the law failed to provide standard form legal entities with limited liability, the transaction costs of creating limited liability by contract are relatively modest -- in contrast to the seemingly unsurmountable costs of using simple contractual means to partition off a firm's bonding assets by shielding them from the personal creditors of the firm's HBIs and managers. To establish limited liability by contract, a the firm itself would simply need to insert, into each contract with its own creditors, a disclaimer of claims against personal assets in each contract with its own creditors - something that might be achieved just by putting the appropriate language in the firm's letterhead. Moreover, the problem of moral hazard is largely absent here, since there is little incentive for a firm's managers not to deploy such disclaimers.

Indeed, limited liability for business firms is a relatively recent invention, and the historical evolution of that invention supports the claim that it was not essential for the development of modern firms. English law did not grant limited liability to manufacturing 
companies until 1855, yet well before then joint stock companies were common, including some with thousands of shareholders (Blumberg). Similarly, from 1849 to 1931, shareholders in business corporations in California bore unlimited pro rata liability for corporate debts, yet publicly traded firms prospered and the state's switch to limited liability in 1931 aroused little attention among the California business community. And, as a more recent example, the American Express Company had, by virtue of its charter, unlimited shareholder liability from the firm's formation in 1850 until 1965. Yet shares in American Express traded freely, and it is not apparent that unlimited liability had an appreciable effect upon either the firm's stock price or its cost of credit (Grossman).

The foregoing reasoning, to be sure, applies principally to limited liability for contractual obligations. Today, in all jurisdictions, legal entities that limit liability in contract also limit the liability of the firm's owners for torts - i.e., accidental or intentional injuries - committed by the firm. To achieve this, law is essential: because the firm generally has no prior contractual relationship with its tort victims, limited liability in tort could not be established by contractual means. Nevertheless, limited liability in tort is arguably not an essential feature of organizational law. As we have argued at length elsewhere, limited liability in tort (as opposed to contract) appears to be an inefficient doctrine that developed largely by historical accident and has been perpetuated by inefficiencies in the political and competitive processes that generate organizational law (Hansmann \& Kraakman, 1991).

\section{SOME LESS IMPORTANT FUNCTIONS OF ORGANIZATIONAL LAW}

Limited liability aside, contemporary literature on the economic functions of organizational law has focused principally on the two basic agency problems facing a large firm: (1) assuring that the firm's managers act in the best interests of the firm's owners, and (2) assuring that majority or controlling owners do not exploit minority or noncontrolling owners (e.g., La Portes, Lopez-de-Silanes, Shleifer, \& Vishny (1998)). While these issues are important, however, and while law is clearly helpful in addressing them, organizational law does not appear to play the same critical role here that it does in permitting asset partitioning. At bottom, these agency problems involve contractual relations, and can be addressed through the mechanisms of private contracting, including privately-provided standard contractual forms and private reputational intermediaries such as stock exchanges and investment banks.

It follows that the minimal number of legal entities necessary for a modern economy is much smaller than the number provided by typical jurisdictions. In principle, only a single form is needed, or perhaps two: one with limited liability as the default rule, the other without. These forms would provide only for basic asset partitioning - permitting the entity to possess its own bonding assets, and governing the personal liability of owners for the firm's debts - and leave all other matters of a firm's organization to contract. Indeed, the recently reformed Delaware 
Business Trust is arguably just such a form. It provides for legal personality (the firm can hold assets and write contracts in its own name, and hence can establish a pool of bonding assets) and for limited liability for the firm's HBIs and managers. Otherwise, it is a blank slate, providing for free contractual stipulation of all aspects of control and distribution of earnings. Since limited liability could easily be waived by a firm formed under the act, it can serve as the basis for both limited liability and unlimited liability forms. With this form in place, the other standard forms provided for by the law of Delaware and other jurisdictions - business corporations, cooperatives, nonprofit corporations, partnerships, limited liability companies, etc. - could all seemingly be dispensed with. They are a substantial convenience, but arguably no more than that.

It also follows that an important subject of inquiry for economic history is to determine the point at which law developed to permit owners of a business to form the business as a legal entity with clearly partitioned assets of its own. It is possible to have a proto-partnership form that provides for collective agency without permitting the firm to own bonding assets of its own. We conjecture that this is the way that partnership law -- which was apparently the earliest form of organizational law for private business activity -- first developed, and we suspect that the ability of the entity to possess its own bonding assets developed much later - perhaps, in Europe, only in recent centuries, simultaneously with the evolution and enormous spread of the large-scale business firms typical of contemporary economies. (In contrast, corporations of a nonprofit character, such as monasteries and universities, had developed as legal entities with their own separate bonding assets much earlier.)

\section{CONCLUSION}

Law plays two critical roles in facilitating contractual relationships. The first is enforcement of agreements. The second is definition of the property rights that can be exchanged. The principal contribution of organizational law lies in the second category. That body of law permits the formation of a floating lien on a pool of assets associated with a given business activity - a form of security interest that could not otherwise be established, and that plays a crucial role in permitting the formation of the large loci of contracts that are employed to organize most modern business activity.

This view of the role of organizational law, we might note, has significant implications concerning the connection between legal structure and economic development. The law's role in mitigating the basic agency problems of large firms has attracted much notice, and the importance to economic development of legal protection for investors has been the subject of substantial research and debate. The analysis offered here, however, suggests that the law plays a much more fundamental role in creditor protection than it does in investor protection. This in turn suggests that any society - and particularly those that are just now developing modern market economies should pay particular attention to developing those aspects of organizational law and related bodies of law - including basic bankruptcy law, equitable subordination doctrine, and fraudulent conveyance doctrine - that permit a firm to easily demarcate and credibly commit a pool of assets 
adequate to bond the firm's contractual commitments.

$-11-$ 


\section{REFERENCES}

Grossman, Peter, The Market for Shares of Companies with Unlimited LiabilityThe Case of American Express, 24 JouRNAL OF LEGAL STUDIES 63 (1995).

Hansmann, Henry, THE OWNERSHIP OF ENTERPRISE (1996).

Hansmann, Henry, and Reinier Kraakman, The Essential Role of Organizational Law (1999).

Hansmann, Henry, and Reinier Kraakman, Toward Unlimited Shareholder Liability for Corporate Torts, 100 YALE LAW JOURNAL 1879-1934 (1991)

Hart, Oliver, FIRMS, CONTRACTS, AND FINANCIAL StRUCTURE (1995).

Jackson, Thomas, and Anthony Kronman, Secured Financing and Priorities Among Creditors, 88 YALE LAW JOURNAL 1143 (1979).

Klein, Benjamin, R. A. Crawford, and Armen Alchian, Vertical Integration, Appropriable Rents, and the Competitive Contracting Process, 21 JoURNAL OF LAW AND ECONOMICS 297 (1978)

La Porta, Rafael, Florencio Lopez-de-Silanes, Andrei Shleifer, \& Robert Vishny, Law and Finance, 106 JOURNAL OF POLITICAL ECONOMY 1113 (1998).

Levmore, Saul, Monitors and Freeriders in Commercial and Corporate Settings, 92 YALE LAW JOURNAL 49 (1982)

Posner, Richard, The Rights of Creditors of Affiliated Corporations, 43 UNIVERSITY OF CHICAGO LAW REVIEW 499 (1976).

Rajan, Raghuram, and Luigi Zingales, The Firm as a Dedicated Hierarchy: $A$ Theory of the Origin and Growth of Firms (1998).

Williamson, Oliver, THE ECONOMIC INSTITUTIONS OF CAPITALISM (1986) 